\title{
Development and reproduction of Trichogramma cacoeciae MARCHAL, 1927 (Hymenoptera: Trichogrammatidae) on Cydia pomonella (LiNNAEUS, 1758) (Lepidoptera: Tortricidae) eggs
}

\author{
MOHAMMED MANSOUR \\ Department of Agriculture, Atomic Energy Commission of Syria, P. O. Box 6091, \\ Damascus, Syria
}

\begin{abstract}
The effects of temperature treatments (15, 20, 25, 30, $\left.35 \pm 1^{\circ} \mathrm{C}\right)$, parasite age, host age, and availability of food on the development and reproduction of the egg parasite Trichogramma cacoeciae on Cydia pomonella eggs, were examined. The results showed that temperature had a profound effect on the mean number of parasitized eggs/females and the survival of immatures to the adult stage. Parasitization was highest on the $1^{\text {st }}$ day after emergence, gradually decreasing for the next 2-10 days (depending on the temperature); it reached a peak at $25 \pm 1{ }^{\circ} \mathrm{C}$. The results also showed an inverse relationship between temperature, developmental time and mean adult longevity; the rate of development increased and longevity decreased with increasing temperature. The availability of food (honey) increased the parasitization rate, and the younger the host (C. pomonella eggs), the more susceptible it was to parasitization.
\end{abstract}

KEY WORDS: Trichogramma cacoeciae, Cydia pomonella, Rearing, Biological control, Egg parasitoids.

\section{INTRODUCTION}

The codling moth, Cydia pomonella (LINNAEUS, 1758), is a key pest of apple orchards in Syria (SCHNEIDER 1957, MANSOUR 2002) and many other countries (BARNES 1991). It is also a major pest on pears, quinces and walnuts and causes tens of millions of dollars in losses to the fruit industry every year. Chemical control of this pest has led to insecticide

* Corresponding author: ascientific@aec.org.sy 
resistance, reduced densities of natural enemies and the creation of secondary phytophagous mite problems (CARDÉ \& MinKS 1995, AL-MOTNY 1997, VODOURIS et al. 2011). In addition, the intensive insecticide spray programme needed to control this pest leaves high insecticide residues on treated fruits, causing difficulties with exporting the crop (BAZOCHE et al. 2014, DAMOS et al. 2015).

Losses to the apple production industry caused by codling moth infestation, control measures and export difficulties have given rise to a new strategy in controlling this pest. The new policy promotes the use of environmentally-friendly methods for protecting apple crops from codling moths. An integrated approach (WITZGALL et al. 2008, MANSOUR 2010, DAMOS et al. 2015, MANSOUR 2015) using agricultural practices, orchard sanitation, pheromones, insect growth regulators (IGR) and natural enemies, particularly egg parasitoids, to control this pest is seriously being considered.

Trichogramma cacoeciae MARCHAL, 1927, an egg parasitoid, was recorded on codling moth eggs collected from the southern part of Syria (AL-MOTNY 2003). The parasitoid has been recorded before on codling moth eggs, particularly in neglected orchards, by several researchers (BARNAY et al. 1999, MANSOUR 2007). This species attacks tortricid eggs in general, but particularly Cydia pomonella and the European grapevine moth, Lobesia botrana (DENIS \& SCHIFFERMÜLLER, 1775) (CROSS et al. 1999, HAIDER et al. 2001, IBRAHIM \& HOLST 2001). Augmentative releases of this species in apple orchards require sound knowledge of the factors affecting reproduction, particularly temperature, food, parasites and host age. Detailed knowledge of how these factors affect Trichogramma cacoeciae reproduction is also important for predicting $T$. cacoeciae reproductive potential and, consequently, its effectiveness under field conditions.

The objective of this study was to examine the effects of certain environmental factors on the development and reproduction of the egg parasites T. cacoeciae on Cydia pomonella eggs. In particular, it was intended to study the effects of temperature on the rate of parasitization, the survival of immatures to the adult stage, adult longevity and the rate of development. Another aim was to study the effects of food (honey as a source of sugar) on the ability of Trichogramma cacoeciae to parasitize tortricid eggs. Finally, it examined the effects of the age of Cydia pomonella eggs on their suitability for parasitization by Trichogramma cacoeciae females and the effects of the age of $T$. cacoeciae females on the mean number of parasitized eggs/female/day. 


\section{MATERIALS AND METHODS}

\section{Rearing Trichogramma cacoeciae}

The strain of $T$. cacoeciae used in this study was collected from the apple production area in the southern part of Syria (Sweida) in 2005 and reared on eggs of the Mediterranean flour moth, Ephestia kuehniella ZELLER, 1879, ever since. Rearing took place in a climatic chamber at $25 \pm 1{ }^{\circ} \mathrm{C}, 50 \pm 10 \% \mathrm{RH}$ and 16: $8 \mathrm{~L}$. D. (light dark cycle). E. kuehniella eggs were glued on to strips $(1.4$ x $6 \mathrm{~cm})$ of pale yellow cardboard ("egg cards") using nontoxic water-soluble glue (arabic gum). A small piece of an "egg card" carrying E. kuehniella eggs infested with Trichogramma cacoeciae was placed in a culture tube $(2.5 \times 20 \mathrm{~cm})$ with a tiny drop of honey on the inner side, after which the tube was plugged with a cotton wad. When the wasps started to emerge, an "egg card" carrying about 900 young (12-24-h old) Ephestia kuehniella eggs, killed by exposure to gamma radiation (MANSOUR 2010), was introduced into the culture tube. The eggs were given about $24 \mathrm{~h}$ to be attacked by the emerging wasps, after which they were transferred to a new, clean culture tube and a new "egg card" with fresh eggs (12-24-h old) was introduced.

\section{Preparing Cydia pomonella eggs for parasitization}

The codling moth eggs used in this experiment were obtained from a codling moth laboratory colony reared on a local diet, similar to that reported by BRINTON et al. (1969). The codling moth colony originated from moths collected from local apple orchards in 1994 and, to maintain genetic variability, males from the natural population were introduced into the colony every summer. Rearing was done in a $27 \pm 1^{\circ} \mathrm{C}, 50 \pm 10 \% \mathrm{RH}$ and 16:8 L. D. cycle. Eggs were obtained from the oviposition cages on sheets of wax paper. These were cut into circular discs about $8.5 \mathrm{~cm}$ in diameter to fit into $9 \mathrm{~cm}$ Petri dishes with 50 codling moth eggs on each disc (surplus eggs were carefully removed).

\section{Effects of temperature on parasitization, longevity and survival to adulthood}

Petri dishes were prepared, each with a disc of wax paper carrying 50 codling moth eggs (1-24-h old). One Trichogramma cacoeciae female was carefully transferred to each dish using a fine hair brush, after which the dishes were covered. The inner side of the dish cover was provided with a tiny drop of honey to feed the female. Twenty-four hours later, the females were transferred to new Petri dishes with codling moth eggs of the same age and number, and the old dishes were incubated at $25 \pm 1{ }^{\circ} \mathrm{C}, 50 \pm 10 \% \mathrm{RH}$ for $T$. cacoeciae development. This process was repeated for as long as the females were alive; female mortality was recorded daily. Four days following incubation at $25 \pm 1^{\circ} \mathrm{C}$, the eggs were evaluated for parasitism (parasitized eggs turn black). The number of parasitized eggs and subsequently also the number of emerging wasps were recorded, and percentage adult 
emergence was determined by dividing the total number of emerged wasps by the number of parasitized eggs. This procedure was repeated at five different temperatures $(15,20,25$, 30 and $35^{\circ} \mathrm{C}, 50 \pm 10 \% \mathrm{RH}$ ) with 30 replicates (30 Petri dishes) being used for each temperature.

\section{Effects of parasite age on the parasitism rate}

The number of parasitized eggs in the previous experiment was recorded daily for every insect and the mean number of parasitized eggs/female/day was calculated. This was done by dividing the total number of Cydia pomonella eggs, parasitized by Trichogramma cacoeciae females at a certain temperature on a particular day, by the total number of living females at that temperature on that particular day.

\section{Effects of age of Cydia pomonella eggs on the parasitism rate}

Petri dishes with wax paper discs each bearing $50 \mathrm{C}$. pomonella eggs were prepared as before. Four age groups of eggs (1-24, 25-48, 49-72 and 73-96-h old) were used, and each age group was replicated 30 times (30 dishes). One Trichogramma cacoeciae female was carefully introduced into each Petri dish; the dishes were provided with a tiny drop of honey and covered. Twenty-four hours later, the females were removed and the Petri dishes incubated at $25 \pm 1^{\circ} \mathrm{C}$ for $T$. cacoeciae development. The Petri dishes were examined 4 days later, the number of parasitized eggs was recorded and the mean number of parasitized eggs/female was calculated.

\section{Effects of temperature on the rate of development}

Petri dishes with wax paper discs each with 50 Cydia pomonella eggs (1-24-h old) were prepared, and five one-day old T. cacoeciae females were carefully introduced into each dish. The Trichogramma cacoeciae females were withdrawn $24 \mathrm{~h}$ later. The dishes were divided into five groups of 30 dishes each, and each group was incubated at one of five different temperatures $\left(15 \pm 1^{\circ} \mathrm{C}, 20 \pm 1^{\circ} \mathrm{C}, 25 \pm 1^{\circ} \mathrm{C}, 30 \pm 1^{\circ} \mathrm{C}\right.$ and $\left.35 \pm 1^{\circ} \mathrm{C}\right)$. The Petri dishes were examined daily and the start of emergence of the wasps was recorded.

\section{Effects of food on the parasitization ability of Trichogramma cacoeciae}

Petri dishes with wax paper discs each carrying 50 codling moth eggs (1-24-h old) were prepared, and a 1-day old T. cacoeciae female was carefully introduced into each dish. The dishes were divided into 2 groups of 30 dishes each. The $1^{\text {st }}$ group of dishes was provided with food (a tiny drop of honey on the inner side of the dish cover), while the $2^{\text {nd }}$ group was left without food (control). Twenty-four hours later, the females were carefully transferred to new Petri dishes similar to the old ones (with codling moth eggs of the same age and with or without food) and the previous dishes were incubated at $25 \pm 1^{\circ} \mathrm{C}$ for $T$. cacoeciae 
development. This process was repeated for five consecutive days (>87\% of the eggs are deposited within the first five days at this temperature). The incubated dishes were examined daily, the number of parasitized eggs was recorded and the mean number of parasitized eggs/female/day was calculated.

\section{Data analysis}

The data generated from the various experiments were subjected to the KolmogorovSmirnov (K-S) test for normality of error distribution and analysis of variance (ANOVA). The treatments were arranged in a completely randomized block design. Data were analysed using the Statview program (version 4.57). A post hoc test to provide specific information on means that were significantly different from each other was carried out using Fisher's protected least significant difference (PLSD) test, at the 5\% level of probability.

\section{RESULTS}

The results of examining the effects of temperature $\left(15-35 \pm 1^{\circ} \mathrm{C}\right)$ on the $T$. cacoeciae parasitization rate, adult longevity, developmental time and survival to adulthood are presented in Table 1. The data clearly show that temperature has a significant effect $(\mathrm{P}<0.0001)$ on all the parameters (parasitization rate, longevity, development and survival to adulthood). The number of parasitized eggs/female reached a maximum at $25 \pm 1^{\circ} \mathrm{C}$ and averaged $27.1,34.1$ and $29.7 \mathrm{eggs} / \mathrm{female}$ at 20,25 and $30 \pm 1^{\circ} \mathrm{C}$, respectively. At the lowest temperature $\left(15 \pm 1^{\circ} \mathrm{C}\right)$, however, the average number of parasitized eggs/female was much lower $(7.2$ eggs/female), and only a few Cysia pomonella eggs/female $(<4)$ were attacked at $35 \pm 1^{\circ} \mathrm{C}$. The effects of temperature on mean adult longevity show that this parameter decreased with increasing temperature, ranging between 21.4 and 4.5 days at 15 and $35 \pm 1^{\circ} \mathrm{C}$, respectively.

Table 1 also presents data on the effects of temperature on the survival of Trichogramma cacoeciae immatures to the adult stage in the same temperature range (15$35 \pm 1^{\circ} \mathrm{C}$ ). The table shows that percentage adult emergence (survival to adulthood) was the highest over the same temperature range suitable for parasitization $\left(20-30 \pm 1^{\circ} \mathrm{C}\right)$. At $15 \pm 1^{\circ} \mathrm{C}$, survival to the adult stage was very low (about $30 \%$ ), whereas at $35 \pm 1^{\circ} \mathrm{C}$ all the insects died before adult emergence.

The results of the effects of temperature on the rate of development of $T$. cacoeciae clearly show that, as in the case of insect development in general, the development of $T$. cacoeciae is temperature-dependent. Up to a certain point, increasing temperature decreased developmental time, but at $35^{\circ} \mathrm{C}$ all the pupae died before emergence. 
Table 1. Effects of temperature on Trichogramma cacoeciae parasitization rate, longevity, development and survival to adults. Temperature - rearing temperature, No. of eggs number of parasitized eggs/female (lifetime fecundity), Long. - female longevity (days), Time - developmental time (days), Survival - survival to adulthood (\%).

\begin{tabular}{|c|c|c|c|c|}
\hline \multirow{2}{*}{ Temperature } & \multicolumn{4}{|c|}{ Mean \pm SD } \\
\cline { 2 - 5 } & No. of egg & Long. & Time & Survival \\
\hline $15 \pm 1^{\circ} \mathrm{C}$ & $7.2 \pm 2.1^{\mathrm{a}}$ & $21.4 \pm 2.95^{\mathrm{a}}$ & $23.0 \pm 0.9^{\mathrm{a}}$ & $30.2 \pm 6.9^{\mathrm{a}}$ \\
\hline $20 \pm 1^{\circ} \mathrm{C}$ & $27.1 \pm 10.6^{\mathrm{b}}$ & $17.9 \pm 4.45^{\mathrm{b}}$ & $17.4 \pm 0.8^{\mathrm{b}}$ & $84.6 \pm 8.0^{\mathrm{b}}$ \\
\hline $25 \pm 1^{\circ} \mathrm{C}$ & $34.1 \pm 4.6^{\mathrm{c}}$ & $14.6 \pm 4.45^{\mathrm{c}}$ & $12.0 \pm 0.8^{\mathrm{c}}$ & $89.5 \pm 3.8^{\mathrm{c}}$ \\
\hline $30 \pm 1^{\circ} \mathrm{C}$ & $29.7 \pm 7.6^{\mathrm{b}}$ & $7.7 \pm 2.0^{\mathrm{d}}$ & $8.2 \pm 0.7^{\mathrm{d}}$ & $89.4 \pm 4.2^{\mathrm{c}}$ \\
\hline $35 \pm 1^{\circ} \mathrm{C}$ & $3.3 \pm 1.9^{\mathrm{d}}$ & $4.5 \pm 1.5^{\mathrm{e}}$ & $0.0 \pm 0.0^{\mathrm{e}}$ & $0.0 \pm 0.0^{\mathrm{d}}$ \\
\hline
\end{tabular}

Means followed by the same letter within each column are not significantly different ( $\mathrm{P}<0.05$, Fisher's LSD test).

Fig. 1 shows data on the effects of $T$. cacoeciae age on the mean number of parasitized eggs/female/day at different temperatures $\left(15-35 \pm 1^{\circ} \mathrm{C}\right)$.

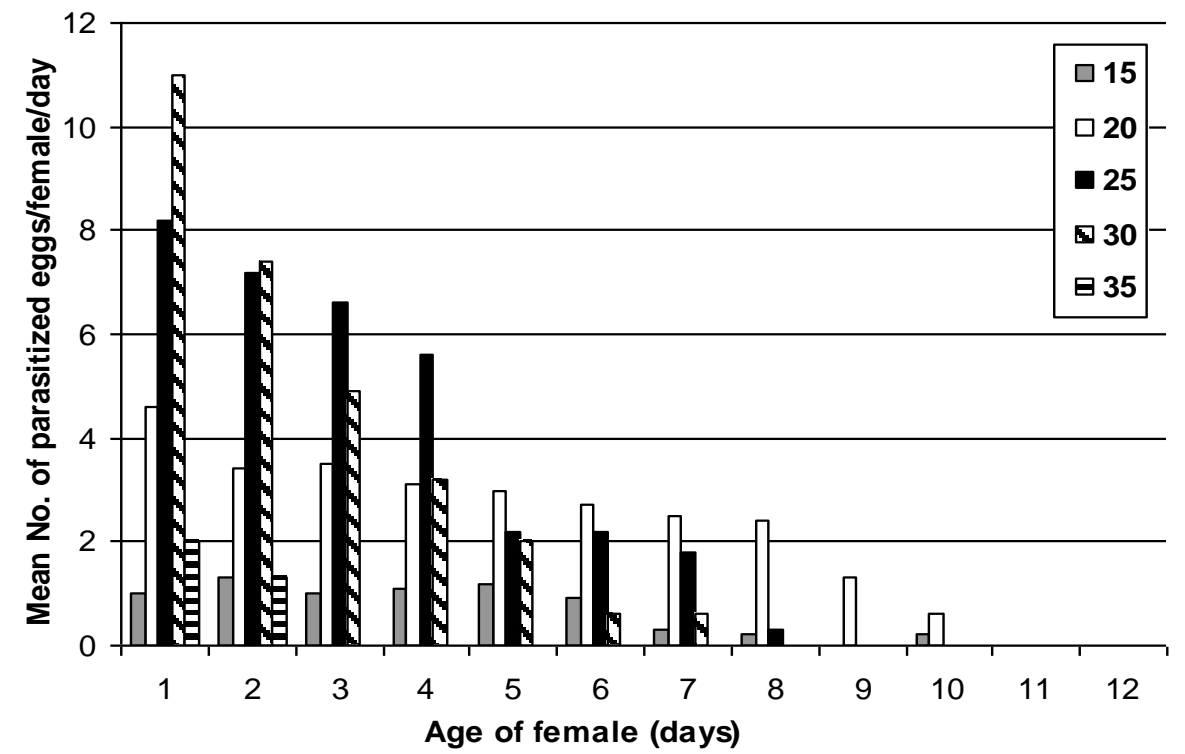

Fig. 1. Effects of age of Trichogramma cacoeciae females on the mean number of parasitized eggs/female/day at different temperatures. 
The age of the parasite significantly affected the mean number of parasitized eggs/female/day ( $\mathrm{P}<0.0001$, Fig. 1) and the greatest proportion of eggs was laid during the first days of life. Parasitization continued for 2-10 days (depending on the temperature), was highest at $25 \pm 1^{\circ} \mathrm{C}$, and the mean number of parasitized eggs/female/day decreased with increasing female age.

The results of the effects of host age (age/developmental stage of Cydia pomonella eggs) on the mean number of parasitized eggs/female are presented in Fig. 2. The age of host eggs significantly affected the mean number of parasitized eggs/female $(\mathrm{P}<0.0001)$. The younger the eggs, the more they were attacked by the parasitic wasps; 1-24-h old $C$. pomonella eggs were the most suitable for parasitization by Trichogramma cacoeciae females. The acceptability of Cydia pomonella eggs to $T$. cacoeciae females, however, decreased with increasing age; 73-96-h old eggs (a few hours before hatching) were the least suitable for parasitization.

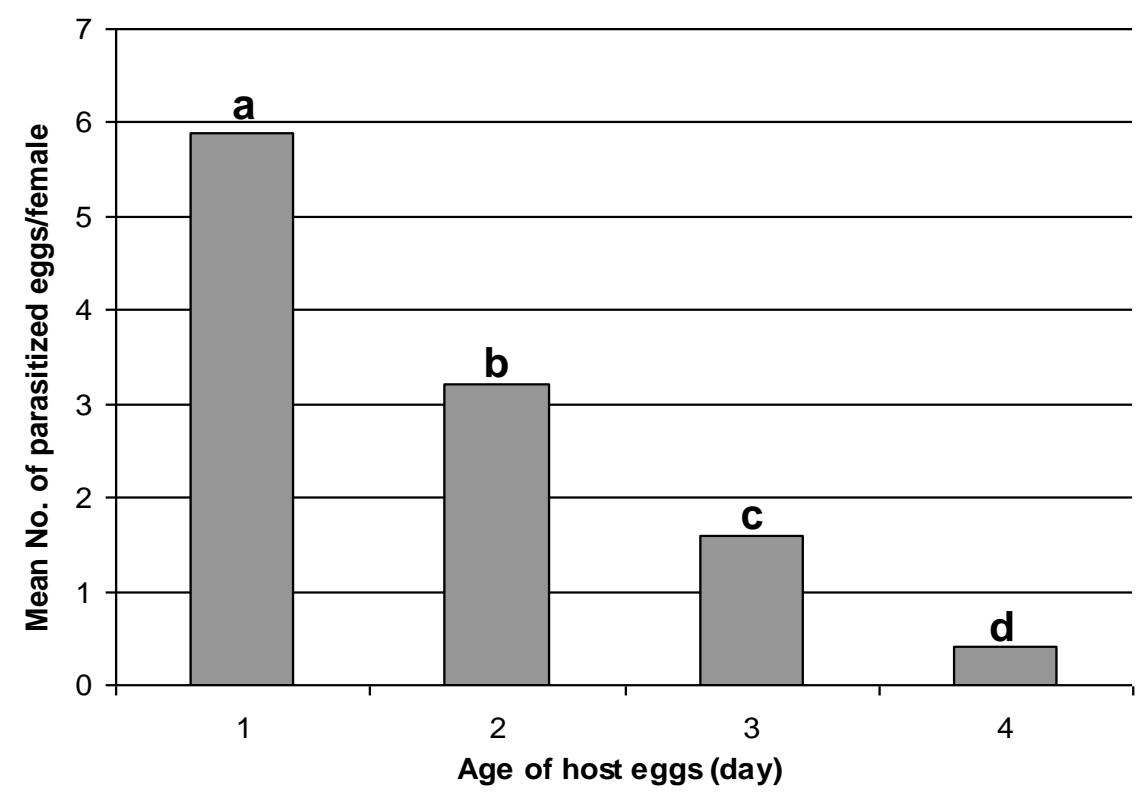

Fig. 2. Effects of host age (Cydia pomonella eggs) on the mean number of eggs parasitized by Trichogramma cacoeciae females.

Fig. 3 lists data on the effects of food on the mean number of parasitized eggs/female/day by Trichogramma cacoeciae females. The addition of honey as food 
significantly increased the female parasitization rate $(\mathrm{P}<0.0001)$. For instance, the mean number of parasitized eggs/female increased by $>37 \%$ when food was provided.

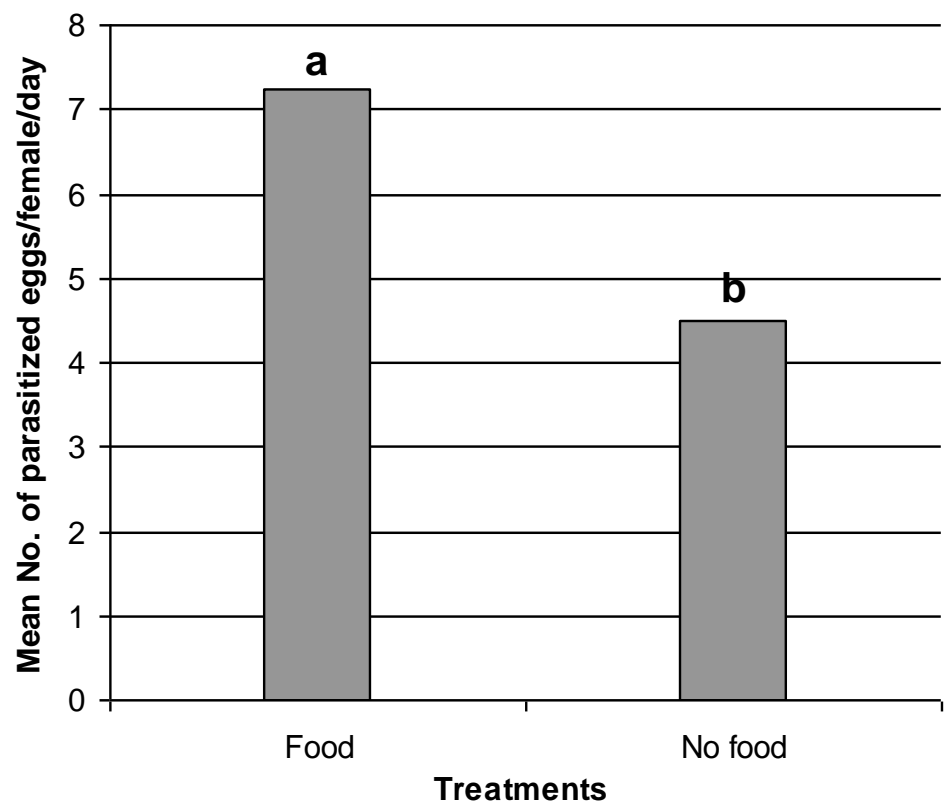

Fig. 3. Effects of food on the mean number of eggs parasitized by Trichogramma cacoeciae females.

\section{DISCUSSION}

The codling moth, Cydia pomonella, is the most destructive insect pest of apple orchards worldwide (CHAPMAN 1973, BARNES 1991) and a key pest of apple orchards in Syria (SCHNEIDER 1957, MANSOUR 2002). Chemical control of this pest has many drawbacks, including insecticide resistance (CARDÉ \& MINKS 1995, AL-MOTNY 1997, REYES et al. 2007, COSTAS et al. 2011), and resistance to biopesticides is developing rapidly (ASSER-KAISER et al. 2007). An integrated approach (WITZGALL et al. 2008, MANSOUR 2010, DAMOS et al. 2015, MANSOUR 2015) using no insecticidal methods at all, involving such approaches as IGR, pheromones and natural enemies, particularly parasitoids, is under consideration or is already being implemented (DAMOS et al. 2015). SMITH (1996) discussed the importance of Trichogramma WESTWOOD, 1833 in the biological control of insect pests, and FERRIERE \& FAURE (1924) regarded Trichogramma 
species as the most important biological control agents for codling moth. In fact, the importance of Trichogramma species in the biological control of insect pests has been known since the late nineteenth century, and the first use of Trichogramma in insect pest control was against the codling moth (DYSART 1973).

Comprehensive knowledge of the factors affecting the reproduction (parasitism) of Trichogramma under field conditions is essential in any augmentative release programme. The present study examined the effects of temperature, food availability and parasite and host age on the development and reproduction of T. cacoeciae on Cydia pomonella eggs. The importance of the results for any Trichogramma cacoeciae release programme in apple orchards in Syria is also discussed.

The results showed that temperature had a profound effect on parasite activity; parasite attack was the most effective between 20 and $30 \pm 1^{\circ} \mathrm{C}$, with the maximum effect at $25 \pm 1{ }^{\circ} \mathrm{C}$. These results are consistent with those reported earlier by several researchers as the optimal range for many Trichogramma species (HARRISON et al. 1985, BOURARACH \& HAWLITZKY 1989, NARANJo 1993, Pizzol 2010, Tian et al. 2017). The results also show that the rate of T. cacoeciae attack peaked during the first day of life, and continued thereafter, though decreasing gradually, for about 8 days at $25 \pm 1^{\circ} \mathrm{C}$. At $15 \pm 1^{\circ} \mathrm{C}$ the parasitization rate was very low, and at $35 \pm 1^{\circ} \mathrm{C}$ all T. cacoeciae pupae died before adult emergence. This is in agreement with reports on other Trichogramma species (TAVARES 1985, PINTUREAU et al. 1981, PAK 1986, CALVIn et al. 1997, BABI \& AL-NABHAn 1998, Ayvazet al. 2008) and on T. cacoeciae (SERYI \& MALChEnKova 1978, Pizzol 2010, MANSOUR 2017). The relatively low number of parasitized eggs/female reported in this study, compared with those reported by MANSOUR (2017) on the same parasitoid on Ephestia kuehniella eggs (about 50\%), could be due to the fact that this Trichogramma cacoeciae strain has been reared on Ephestia kuehniella eggs for many generations. In fact, it has been shown that the degree of acceptance of Trichogramma species for a particular host may be related to their previous rearing host (KLOMP et al. 1979, MiURA et al. 1994).

Considering the fact that commercial apple orchards in Syria are grown at more than $700 \mathrm{~m}$ above sea level $(700-1700 \mathrm{~m})$, where summer temperatures do not often reach $35 \pm 1^{\circ} \mathrm{C}$, this parasite could play an important role in controlling Cydia pomonella under orchard conditions. Moreover, Trichogramma cacoeciae was reared in this experiment at a continuous temperature of $35 \pm 1^{\circ} \mathrm{C}$, which is not the case in nature, where the temperature fluctuates very often between day and night and even during the daytime (lower in the morning and afternoon). Furthermore, although no survival of $F_{1}$ insects was observed at $35 \pm 1^{\circ} \mathrm{C}$ (the insects died before they could emerge), some parasitization was observed at this temperature.

Trichogramma species are usually released as pupae; consequently, knowing the age limits of the parasitoids under a given set of environmental conditions is important in 
determining release frequency. The results of this study show that mean female longevity and developmental time (from egg to adult) decreased significantly with increasing temperature. Female longevity ranged between 21.4 and 4.5 days for insects reared at 15 and $35 \pm 1{ }^{\circ} \mathrm{C}$, respectively. Similarly, development from egg to adult ranged from 23 to 8.2 days at the same temperatures $\left(15-30 \pm 1^{\circ} \mathrm{C}\right)$ in the same order. These results are in agreement with those reported before for some other Trichogramma species. The developmental rate and longevity of Trichogramma species are inversely related to temperature (CABEllo \& VARGaS 1988, SMith 1996, AYvaS et al. 200, ÖZDER \& Kara 20108, PIZZOL et al. 2010); the same applies to T. cacoeciae (MANSOUR 2017).

REZNIK et al. (1997) showed that host age is one of the most important factors in determining host acceptance by females in Trichogramma. The results of this study show that young host eggs are more acceptable for parasitization than older ones and that the acceptability of host eggs to parasite attack decreases with increasing age. This is in agreement with data reported earlier by several other researchers (MAKEE 2005, MORENO et al. 2009, Perveen et al. 2012, Mansour 2017, Tian et al. 2017). The decreasing acceptability of codling moth eggs to parasitization with increasing age may be due to the hardening of the egg chorion or the development of the embryo inside the egg (CALVIN et al. 1997, REZNIK et al. 1997, BARNAY et al. 1999).

Food in the form of honey was shown to play an important role in the reproduction of this species: providing food significantly increased the parasitization rate. These results are in agreement with those reported by other researchers (HEGAZI et al. 2000, ZHANG et al. 2004, Garcia-SalaZar et al. 2007, Marko et al. 2012, MiÑarro \& Prida 2013, SOnG et al. 2014): they emphasize the importance of leaving flowering plants with their nectar as possible food sources in orchards to feed natural enemies or even of planting such vegetation in orchards.

In summary, the release of hymenopterous egg parasitoids, particularly Trichogramma for controlling Lepidopterous pests, was put forward as an important component of insect pest management programmes already more than two decades ago (Li 1994, SMITH 1996). Trichogramma species are also among the most important parasitoids used for insect pest control because they are easy to rear at an acceptable cost (SMITH 1996). The effects of several species of Trichogramma as potential candidates for codling moth control have been examined before (DolPHIN et al. 1972, KARADZHOV 1974, HASSAN et al. 1988, Cossentine et al. 1996, Bloem et. al. 1998, SigsgaARD et al. 2017). In fact, species belonging to the family Trichogrammatidae are the only ones that attack tortricid eggs (Cross et al. 1999). In addition, Trichogramma species are the only natural enemies of the codling moth that kill this pest before it can cause any damage - the eggs are killed before they can hatch. This paper provides data on the development and reproduction of $T$. cacoeciae on eggs of the target host, Cydia pomonella, under different environmental 
conditions. The data clearly show that Trichogramma cacoeciae may be a good candidate for Cydia pomonella control within a temperature range of $20-30 \pm 1{ }^{\circ} \mathrm{C}$. In addition, such data should be very useful for the mass rearing of Trichogramma cacoeciae, predicting its performance in the field and, consequently, the efficacy of released $T$. cacoeciae females under orchard conditions.

\section{ACKNOWLEDGEMENTS}

The author would like to thank Dr I. OTHMAN, Director General of the Syrian Atomic Energy Commission and Dr F. KURD-ALI, Head of the Department of Agriculture for supporting this project. This research was supported, in part, by the International Atomic Energy Agency, Vienna, Austria (Res. Contract No. SYR/15574).

\section{REFERENCES}

AL-Motny W. 1997. Ecological studies on the woolly apple aphid, Eriosoma lanigerum (Hausmann) in Sweida and Zabadani regions. M. Sc. Thesis, Damascus University, Damascus, Syria.

AL-Motny W. 2003. Evaluation of codling moth, Cydia pomonella (L.), biological control agents in the Sweida area. Ph. D. thesis, Damascus University, Damascus, Syria.

Asser-Kaiser S., Fritsch E., Undorf-Spahn K., KienZle J., Eberle K.E., Gund N.A., ReineKe A., ZebitZ C.P.W., Heckel D.G., Huber J., Jehle J.A. 2007. Rapid Emergence of Baculovirus Resistance in Codling Moth Due to Dominant, Sex-Linked Inheritance. Science, 317 (5846): 1916-1918.

Ayvaz A., Karasu E., Karabörklü S., TunçBileK A.K. 2008. Effects of cold storage, rearing temperature, parasitoid age and irradiation on the performance of Trichogramma evanescens WeSTwOod (Hymenoptera: Trichogrammatidae). Journal of Stored Product Research, 44 (3): $232-240$.

BABi A., AL-NabHan M. 1998. Effects of temperature on some biological characteristics of the Syrian populations of Trichogramma principium SUGONYAEV \& SOROKINA (Hym., Trichogrammatidae). Arab Journal of Plant Protection, 16 (2): 66-73.

BARNES M.M. 1991. Codling moth occurrence, host, race formation, and damage. [in:] L.P.S. vAN DER GeEST, H.H. EvenhuIS (eds.). Tortricid pests, Volume 5. Their biology, natural enemies and control. Elsevier, Amsterdam, 313-328.

Barnay O., Pizzol J., Gertz C., Kienlen J.C., Hommay G., Lapchin L. 1999. Host DensityDependence of Discovery and Exploitation Rates of Egg Patches of Lobesia botrana (Lepidoptera: Tortricidae) and Ephestia kuehniella (Lepidoptera: Pyralidae) by the Parasitoid Trichogramma cacoeciae (Hymenoptera Trichogrammatidae). Journal of Economic Entomology, 92 (6): 1311-1320. 
Bazoche P., Combris P., Giraud-Héraud E., Seabra Pinto A., Bunte F., Tsakiridou E. 2014. Willingness to pay for pesticide reductions in the EU: nothing but organic? European Review of Agricultural Economics, 41 (1): 87-109.

Bloem S., Bloem K.A., Knight A.L. 1998. Oviposition by sterile codling moths, Cydia pomonella (Lepidoptera: Tortricidae) and control of wild populations with combined releases of sterile moths and egg parasitoids. Journal of the Entomological Society of British Columbia, 95: 99-109.

BOURARACH K., HAWLITZKY N. 1989. Comparative study of the biological potential of Trichogramma evanescens WeSTWOOD and Trichogrammatoidea lutea GiRAUlT (Hym., Trichogrammatidae). Entomophaga, 34 (1): 95-104.

Brinton F.E., Proverbs M.D., CARTy B.E. 1969. Artificial diet for mass production of the codling moth, Carpocapsa pomonella (Lepidoptera: Olethreutidae). The Canadian Entomologist 101 (6): $577-584$.

Cabello T., Vargas P. 1988. The effects of temperature on bionomics of Trichogramma cordubensis (Hymenoptera: Trichogrammatidae). [in:] J. Voegele, J. WAage J. VAN LenTERen (eds.). Trichogramma and other egg parasites. Les trichogrammes et autres parasitoides oophages. $2^{\text {nd }}$ International Symposium. 2e Symposium international Guangzhou (Chine), 10-15 novembre 1986. Les Colloques de l'INRA n 43. Institut National de la Recherche Agronomique, Paris, 155-164.

CAlvin D.D., Losey J.E., KnAPP M., Poston F.L. 1997. Oviposition and Development of Trichogramma pretiosum (Hymenoptera: Trichogrammatidae) in Three Age Classes of Southwestern Corn Borer Eggs. Environmental Entomology, 26 (2): 385-390.

CARDÉ R.T., Minks A.K. 1995. Control of Moth Pests by Mating Disruption: Successes and Constraints. Annual Review of Entomology, 40: 559-585.

Chapman P.J. 1973. Bionomics of the Apple-Feeding Tortricidae. Annual Review of Entomology, 18: $73-96$

Cossentine J.E., Lemieux J., Zhang Y. 1996. Comparative Host Suitability of Viable and Nonviable Codling Moth Eggs for Parasitism by Trichogramma platneri (Hymenoptera: Trichogrammatidae). Environmental Entomology, 25 (1): 1052-1057.

Cross J.V., SOlomon M.G., BABANDreier D., Blommers L., EASTTERbrook M.A., JAy C.N., JenSER G., Jolly R.L., Kuhlmann U., Lilley R., Olivella E., Toepter S., Vidal S. 1999. Biocontrol of Pests, of Apples and Pears in Northern and Central Europe: 2. Parasitoids. Biocontrol Science and Technology, 9 (3): 277-317.

Damos P., Colomar L.A., IoRiatti C. 2015. Integrated Fruit Production and Pest Management in Europe: the Apple Case Study and How Far We Are From The Original Concept? Insects, 6 (3): 626-657.

DolPhin R.E., Cleveland M.L., Mouzin T.E., MorRison R.K. 1972. Releases of Trichogramma minutum and T. cacoeciae in an Apple Orchard and the Effects on Populations of Codling Moths. Environmental Entomology, 1 (4): 481-484.

DYSART R.J. 1973. The use of Trichogramma in the USSR. [in:] Proceedings of the Tall Timbers Conference, February 24-25, 1972. Tall Timbers Research Station, Tallahassee, Florida, 165-173.

Ferriere C., FAure J.C. 1924. Sur Trichogramma evanescens, WeStw., parasite des oeufs de Pieris brassicae, L. Revue de Pathologie Végétale et d'Entomologie Agricole de France, 11 (2): 104-118. 
Garcia-Salazar C., Gut L.J., Whalon M.E. 2007. Hedgerow barriers and other reduced-risk controls for managing Oriental fruit moth, Grapholita molesta (BUSCK) (Lepidoptera: Tortricidae) in apples. Renewable Agriculture and Food Systems, 22 (3): 181-188.

HAider N., Monje J.C., ZeBitz C.P.W. 2001. Mechanism regulating the interspecific competition of two sympatrically occurring species of Trichogramma. Egg Parasitoid News, 13: 10.

HaRRISON W.W., KING E.G., OuZTS J.D. 1985. Development of Trichogramma exiguum and T. pretiosum at Five Temperature Regimes. Environmental Entomology, 14 (2): 118-121.

Hassan S.A., KohleR E., Rost W.M. 1988. Mass production and utilization of Trichogramma: 10. Control of the codling moth, Cydia pomonella and the summer fruit tortrix moth Adoxeles orana (Lep.: Tortricidae). Entomophaga, 33 (4): 413-420.

Hegazi E.M., Khafagi W.E., Hassan S.A. 2000. Studies on three species of Trichogramma I. Foraging behavior for food or host. Journal of Applied Entomology, 124 (3-4): 145-149.

IBRAHIM R., Holst H. 2001. Occurrence and distribution of Trichogramma spp. in vineyards. Egg Parasitoid News, 13: 10.

KARADZHOV S. 1974. Efficiency of some Trichogramma spp. (Hymenoptera: Chalcididae) in controlling the codling moth (Carpocapsa pomonella L.). Gradinarska i Lozarska Nauka, 11 (1): 49-56. (in Russian)

Klomp H., Teerink B., Wei Chun M. 1979. Discrimination Between Parasitized and Unparasitized Hosts in Egg Parasitoid Trichogramma embryophagum (Hymenoptera: Trichogrammatidae): a Matter of Learning and Forgetting. Netherlands Journal of Zoology, 30 (2): 254-277.

Li L.Y. 1994. Worldwide use of Trichogramma for biological control on different crops: a survey. [in:] E. WAJNBERG, S.A. HASSAN (eds.). Biological control with egg parasitoids. CAB International, Wallingford, 37-53.

MAKEE H. 2005. Factors influencing the parasitism of codling moth eggs by Trichogramma cacoeciae MARCH. and T. principium Sug. et SOR. (Hymen. Trichogrammatidae). Journal of Pest Science, 78 (1): 31-39.

Markò V., Jenser G., Mihàlyi K., Hegyi T., Balàzs K. 2012. Flowers for better pest control? Effects of apple orchard groundcover management on mites (Acari), leaf miners (Lepidoptera, Scitellidae), and fruit pests. Biocontrol Science and Technology, 22 (1): 39-60.

MANSOUR M. 2002. Phenology of the codling moth, Cydia pomonella (L.) in the southern part of Syria and its damage to apple fruit. Polish Journal of Entomology, 71 (2): 79-89.

MANSOUR M. 2007. Potential for integrating SIT, parasitoids and pheromones for codling moth, Cydia pomonella (L.) control in Syria. [in:] Final FAO/IAEA research co-ordination meeting on "Improving of codling moth SIT to facilitate expansion of field applications", Vacaria, Brazil. March 19-23. IAEA TECDOC 314-D4-876.4. IAEA, Vienna, Austria., 1-19.

MANSOUR M. 2010. Effects of gamma radiation on the Mediterranean flour moth, Ephestia kuehniella, eggs and acceptability of irradiated eggs by Trichogramma cacoeciae females. Journal of Pest Science, 83 (3): 243-249.

MANSOUR M. 2015. Effects of gamma radiation on the Mediterranean flour moth, Ephestia kuehniella ZELLER, mature larvae and acceptability of irradiated larvae by Bracon hebetor SAY females. Journal of the Stored Product Research, 60: 43-47. 
MANSOUR M. 2017. Development and reproduction of Trichogramma cacoeciae on Ephestia kuehniella eggs: important factors to consider. [in]: Third FAO-IAEA International Conference on Area-wide Management of Insect Pests: Integrating the Sterile Insect and Related Nuclear and Other Techniques. Book of Abstracts. Vienna, Austria, 22-26 May, 2017, 326.

MiÑARRo M., PridA E. 2013. Hedgerows surroundings organic apple orchards in north-west Spain: potential to conserve beneficial insects. Agricultural and Forest Entomology, 15 (4): 382-390.

Miura K., Matsuda S., Kobayashi M. 1994. Discrimination between Parasitized and Unparasitized Hosts in an Egg Parasitoid Trichogramma chilonis IsHII (Hymenoptera: Trichogrammatidae). Applied Entomology and Zoology, 29 (3): 317-322.

Moreno F., Pérez-Moreno I., Marco V. 2009. Effects of Lobesia botrana (Lepidoptera: Tortricidae) Egg Age, Density and UV Treatment on Parasitism and Development of Trichogramma cacoeciae (Hymenoptera: Trichogrammatidae). Environmental Entomology, 38 (5): 1513-1520.

NARANJO S.E. 1993. Life History of Trichogrammatoidea bactrae (Hymenoptera: Trichogrammatidae), an Egg Parasitoid of Pink Bollworm (Lepidoptera: Gelechiidae), with Emphasis on Performance at High Temperatures. Environmental Entomology, 22 (5): 1051-1059.

ÖZDER N., KARA G. 2010. Comparative biology and life tables of Trichogramma cacoeciae, T. brassicae and T. evanescens (Hymenoptera: Trichogrammatidae) with Ephestia kuehniella and Cadra cautella (Lepidoptera: Pyralidae) as hosts at three constant temperatures. Biocontrol Science and Technology, 20 (3): 245-255.

PAK G.A. 1986. Behavioral variation among strains of Trichogramma spp.: A review of the literature on host selection. Journal Applied Entomology, 101 (1-5): 55-64.

PerveEn F., Sultan R., Ul-Haque E. 2012. Role of temperature and hosts (Sitotroga cereallela and Corcyra cephalonica) egg age on the quality production of Trichogramma chilonis. Arthropods, 1 (4): 144-150.

Pintureau B., Babault M., Voegele J. 1981. Étude de quelques facteurs de variation de la fécondité chez Trichogramma maidis Pintureau et Voegele (Hym. Trichogrammatidae). Agronomie, 1 (4): 315-322.

Pizzol J., Pintureau B., Khoualdia O., Desneux N. 2010. Temperature-dependent differences in biological traits between two strains of Trichogramma cacoeciae (Hymenoptera: Trichogrammatidae). Journal of Pest Science, 83 (4): 447-452.

Reyes M., Franck P., Charmillot P.-J., Ioriatti C., Olivares J., Pasqualini E., Sauphanor B. 2007. Diversity of insecticide resistance mechanisms and spectrum in European populations of the codling moth, Cydia pomonella. Pest Management Science, 63 (9): 890-902.

REZNiK S.YA, UMAROVA T.YA., VoINOVICH N.D. 1997. The influence of previous host age on current host acceptance in Trichogramma. Entomologia Experimentalis et Applicata, 82 (2): 153-157.

SCHNEIDER F. 1957. Report to the government of Syria on insect pests of fruit trees and some other crop. FAO Report No. 664. Rome, Italy.

SERYi N.I., MALCHENKOVA N.I. 1978. Factors regulating the effectiveness of trichogrammatid egg parasites in their colonisation in Moldavian apple orchards. Izvestiya Akademii Nauk Moldavskoy SSR, Seriya Biologichekikh i Khimiceskikh Nauk, 1978 (6): 49-54. (in Russian) 
SigsgaArd L., Herz A., Korsgarrd M., Wuhrer B. 2017. Mass Release of Trichogramma evanescens and T. cacoeciae Can Reduce Damage by the Apple Codling Moth Cydia pomonella in Organic Orchards under Pheromone Disruption. Insects, 8 (2): 41.

SMITH S.M. 1996. Biological control with Trichogramma: advances, successes, and potential of their use. Annual Review of Entomology, 41: 375-406.

Song B., Jiao H., TANG G., Yao Y. 2014. Combining repellent and attractive aromatic plants to enhance biological control of three tortricid species (Lepidoptera: Tortricidae) in an apple orchard. Florida Entomologist, 97 (4): 1679-1689.

TAVARes J. 1985. Étude comparée de trois espèces de Trichogrammes: T. maidis PINTUREAU et Voegelé, T. buesi Voegelé et T. embryophagnum Hartig (Hym., Trichogrammatidae). Ph. D. Thesis, Université de Droit, d'Economie et des Sciences d'Aix-Marseille III. Aix-en-Provence, France.

Tian J.C., WAng Z.C., Wang G.R., Zhong L.Q., Zheng Xs., Xu H.X., Zang L.S., Lu Z.X. 2017. The Effects of Temperature and Host Age on the Fecundity of Four Trichogramm Species, Egg Parasitoids of the Cnaphalocrocis medinalis (Lepidoptera: Pyralidae). Journal of Economic Entomology 110 (3): 949-953.

Vodouris C.C., Sauphanor B., Franck P., Reyes M., Mamuris Z., Tsitsipis J.A., Vontas J., MARGARItOPOULOS J.T. 2011. Insecticide resistance status of the codling moth, Cydia pomonella (Lepidoptera: Tortricidae) from Greece. Pesticide Biochemistry and Physiology, 100 (3): 229-238.

Witzgall P., Stelinski L., Gut L., Thomson D. 2008. Codling moth management and chemical ecology. Annual Review of Entomology, 53 (1): 503-522.

Zhang G., Zimmermann O., Hassan S.A. 2004. Pollen as a source of food for egg parasitoids of the genus Trichogramma (Hymenoptera: Trichogrammatidae). Biocontrol Science and Technology, 14 (2): 201-209.

Received: 9 July 2018

Accepted: 21 September 2018 